\title{
Immunity Clause under the 1999 Constitution of Nigeria: A Dire Need for Reform
}

\author{
Francis N. Ukoh ${ }^{1} \&$ Rita A. Ngwoke ${ }^{2}$ \\ ${ }^{1}$ Legal Practitioner and Notary Public of Nigeria, Amoretti Chambers, 5 Agadez Street, Wuse II Abuja, Nigeria, \\ E-mail: frankoh01fn@gmail.com \\ ${ }^{2}$ Senior Lecturer, College of Law Igbinedion University, Okada, Edo State, Nigeria \\ Correspondence: Rita A. Ngwoke, College of Law, Igbinedion University, Okada, Edo State, Nigeria. E-mail: \\ sunshinengwoke@gmail.com
}

Received: November 11, 2020

Accepted: December 17, 2020

Online Published: December 27, 2020

doi:10.5539/jpl.v14n2p47

URL: https://doi.org/10.5539/jpl.v14n2p47

\begin{abstract}
Immunity clause as enshrined under section 308 of the 1999 Constitution of the Federal Republic of Nigeria has generated protracted controversies for and against its inclusion in the rubrics of Nigerian constitutional laws. This paper considers widespread corruption by Nigerian leaders, shielded by the immunity clause. It explains the need for reform to curtail the anomaly wherein absolute executive immunity is provided for leaders in Nigeria. The paper maintains that there should be equality before the law, hence, the possible prosecution and appearance of a sitting President, Vice President, Governors and Deputy Governors in some criminal and civil matters drawing from other jurisdictions.
\end{abstract}

Keywords: immunity clause, jurisprudence, president, prime minister, governors

\section{Introduction}

The executive immunity enshrined in section 308 of the 1999 Constitution of the Federal Republic of Nigeria (as amended) has raised much controversy among scholars and Politicians alike (Olanikpekun, 2005; Udeh, 2009; Umoru, 2020; Azu, 2020). It has been criticised as an enablement of high-level corruption and a colossal waste of the nation's common wealth by those in whose hands it is entrusted, because it shields them from justice and promotes the culture of impunity. Since the onset of the fourth republic in 1999, no fewer than twenty-three former governors have been arrested or prosecuted for corruption (Human Rights Watch [HRW], 2011). Of this number, only six have been sentenced to various terms of imprisonment within and outside Nigeria (HRW, 2011; Ifeanyi, Ojukwu and Nnamani, 2019; The Write House [WH], 2014). This number, however, is abysmal in comparison to the 17 former governors facing different degrees of criminal charges in Nigerian courts and those still under investigation by the Economic and Financial Crimes Commission (HRW, 2011; Akinpelu, 2020; Eniola and Tobi, 2019, Daudu, 2010). ${ }^{1}$ Indeed, the immunity clause has become an albatross to Nigeria's democracy and economic growth and development. This has led to various calls for removal of this clause from the Constitution to give room for better accountability and responsibility in governance, especially against the fact that other countries have slowly but steadily moved away from shielding their political representatives from criminal prosecution for corruption and misappropriation of public fund (Holmes, 2020; Olugbebga, 2012; U.S. Constitution). ${ }^{2}$

This paper examines the existing framework on executive immunity in Nigeria with a view to determining the need for reform. Part 1 is the introduction. Part 2 explores the history and meaning of the immunity clause. Part 3, on the other hand, examines the jurisprudence of the immunity clause in Nigeria, while Part 4 makes a comparative review of the clause with other jurisdictions and argues that because sovereignty belongs to the people, political representatives must be made to account to the people regarding their stewardship. Part 5 is the conclusion.

\section{The Origin and Meaning of Executive Immunity}

The origin of executive immunity can be traced to the immunity of the sovereign or crown and his dominion over all his nationals. Initially, this was practiced by the Church and the Papacy (Peace Treaty of Westphalia, 1648; Gross, 1948) when it had dominion over all nations, but when these nations began to kick against it, national sovereignty and the supremacy of kings over their respective domains became more prominent (Ukoh, 2018).

By the seventeenth century, however, absolute monarchy had gradually faded away as jurists favoured the 
progressive erosion of monarchical power over political representation (Udeh, 2009). Notwithstanding, the idea of equality of sovereigns had already been firmly implanted in international relations, which became the bastion of sovereign executive immunity - that 'one sovereign could not exercise dominion over; another encapsulated in the maxim par in parem non habet imperium (Udeh, 2009; Fombad and Inegbedion, 2010). The doctrine became assimilated by common law under the adage that the 'sovereign, crown or state could do no legal wrong' and that it is immune from civil suit or criminal prosecution - rex non potest peccara (Udeh, 2009). Thus, the domestic application of executive immunity had benefited immensely from the medieval perception of sovereignty residing in the ruler or crown absolutely. In certain jurisdictions, this has translated to mean that the executive i.e. the president, the vice President, regional or state governors and deputy governors enjoy immunities in their official capacity (Tajudeen, 2013).

Indeed, John Austin in his 'Province of Jurisprudence' puts it thus; "positive law or every law simply and strictly so-called, is set directly or circuitously by a sovereign or body to a member of the independent political society wherein that person or body is sovereign or supreme" (Austin, 1832: 11).

Sovereignty is the power of the State to make and enforce law with all force or sanction, and it is subject to no other authority (Garner, 2004). The word 'sovereign' is derived from a Latin word superanus meaning supremacy, (Appadorai, 2004) while 'immunity' is defined as the State of being protected from something (Hornby, 2001). The phrase 'sovereign immunity', on the other hand, can be explained as the protection of the King or his successor, the democratic executive President, Vice President, Governor or Deputy Governor from prosecution or any duty, liability or service of the judicial process (Hornby, 2001; Garner, 2004). In Nigeria, this immunity is provided in section 308 of the Constitution (Constitution of the Federal Republic of Nigeria [CFRN], 1999). This purports that nobody can institute or continue civil or criminal proceedings against an executive head both at the central or federal government and in the states. Similarly, these persons cannot be arrested or imprisoned, or can anybody compel their appearance in court during the pendency of their term in office.

\section{The Jurisprudence of Immunity Clause in Nigeria}

It is shown that the major reason for the continued retention of the immunity clause in most countries' constitutions is the need to prevent unnecessary distraction of those in executive authority from the primary duty of governance (Obih v. Mbakwe; 1984). However, this temporary respite from civil and criminal litigation (domestically and internationally) has proven in many jurisdictions, especially third world countries, to be an ideal cover for the involvement of state officials in unwholesome activities, including corruption, trafficking (drugs and human) and violence (Fombad and Nwauche, 2012; Gberie, 2016). This reality has led to the questioning of whether it is still pertinent to retain this clause in domestic legal systems. Indeed, laws are meant to govern human behaviour, and therefore they must remain relevant to social realities and the competing claims of justice. Laws should flow from the purview of equality, fairness and justice. Thus, according to Appadorai:

Man's inequality is one striking feature of humans. Men are unequal in terms of their body proportion, physical strength, intellectual abilities and moral capacity. But we must admit that if an individual is free to do what he pleases unchecked, the clever and more capable will use their freedom to concentrate all wealth and power in themselves to the misery and oppression of the rest. It, therefore, means that no one man well-endowed ought to use his authority arbitrarily, exorbitantly or abuse his office for personal advantage. As a matter of fact, man is equal as a matter of rationality, civil equality, political equality and economic equality (Appadorai, 2004: 87).

We are of the opinion that the immunity clause enshrined in the Nigerian Constitution does not rest on any ideals of equality, fairness and justice. In fact, from the pragmatist point of view, the President, Vice Presidents, Governors and their Deputies are sacred cows in the Nigerian polity, as their immunity subsists both during their tenure in office and afterwards in respect of anything done while in office. Without equivocation, this wide latitude of immunity is a temptation for even the most sanctimonious of people given the high level of societal decadence. No person should be made above the law without exception, including the head of State; otherwise, the rule of man rather than the rule of law shall prevail to the detriment of society (Amaechi, 2004). This can be gleaned from the case of Abacha v. Fawehinmi, (2000) where the issue arose whether the $1^{\text {st }}$ cross-respondent, as the Head of State of Nigeria, is immune from civil and criminal actions in all cases. The Supreme Court stated that the immunity clause provided by the Constitution does not apply to the Head of State in his official capacity or criminal or civil proceeding in which he is only a nominal party. The court had no choice since none of the learned justices could muster the courage to face the fiend consequence of the Military Junta.

Flowing from the above, section 308(1)(a) posits that actions, whether criminal or civil, cannot be brought against 
the President, the Vice President and the Governors of the various states and their Deputies no matter the circumstances (Tinubu v. I.M.B. Securities, 2001). Subsection (2) of this section however, creates an exemption in the case of civil matters where these persons are sued in their official capacity or as nominal parties, i.e. where they are merely joined in the matter to avoid procedural defects without any financial obligation. This is a systematic way of enforcing the clause considering that the presence of a nominal party in court is of no effect and cannot be regarded as an exception because it merely permits the order of the day. Furthermore, it is provided that they cannot be arrested or imprisoned during their period in office and no proceedings can be brought against them (CFRN, 1999)

This implies that the category of persons conferred with immunity under section 308 cannot be subjected to any criminal process for any act or omission done while in office and even for acts previously committed, which remain pending. This is very unfortunate, especially for those executive officials who had pending criminal matters before elevation into the exalted offices covered by immunity. A good case in point is Fawehinmi v. I.G.P. (2002) where Chief Gani Fawehinmi sought an order of mandamus against the Inspector General of Police at the Federal High Court to compel him to investigate the allegations of crime against Bola Ahmed Tinubu, the then sitting Governor of Lagos state. The trial court dismissed the originating summons, and Chief Gani appealed to the Court of Appeal. At the Court of Appeal, the court held, inter alia:

Under section 4 of the Police Act, the police have a duty to detect crime. Implicit in that duty is the duty to investigate complaints on the commission of crimes, and that does not hold or protect the persons covered under section 308(3) from the police investigation. But what section 308(1)(b) of the 1999 Constitution means is that a person to whom the section applies shall not for any reason whatsoever be arrested or imprisoned in pursuance of the process of a court, tribunal or any other body which under the law has the power to issue a process which may result in a person concerned to be arrested or imprisoned (Fawehinmi v. I.G.P, 2002: 640).

On further appeal to the Supreme Court, the decision of the Court of Appeal was upheld. The court blew hot and cold in interpreting section 308(1)(b) when it held that the police could investigate public office holders but that they cannot arrest or imprison them pursuant to the provision. Though this interpretation was novel at this point, the court might have taken cognizance of the fact that the matter was already in court before Bola Ahmed Tinubu was sworn in as Governor. However, despite the decision, which was supposed to transform the operation of security agencies in relation to persons covered by executive immunity, we are not sure that it achieved the desired objective of chronicling the past and current offences committed by those enjoying executive immunity while they serve their terms in office. No wonder, nothing more was heard of the police investigation of Bola Ahmed Tinubu after the Supreme Court decision, even after he left office in 2007. This is actually an invitation to recklessness on the part of executive officials who enjoy the rare privilege of immunity. It is obviously a blank check for them to embezzle money, own properties in choice places around the world, and to do with the ill-gotten wealth whatever they desire at the expense of millions of Nigerians. ${ }^{3}$ Our respectful view is that persons with pending matters in court (which puts their character in question) ought to be investigated and restrained from taking responsible roles covered by the immunity clause until such matters come to finality because it is better to delay than fast track them to power.

Paragraph (c) of section 308(1) further exempts the category of executives covered by the immunity clause from being compelled through any court processes to appear in court for any reason whatsoever, and prohibits any application to issue such processes. Perhaps, the reason for this provision is to prevent situations where the court may issue processes that are rendered nugatory by virtue of the fact that they are issued against a person that may disregard them without any consequences. Subsection (1) of section 308 also contains a proviso, which shows that the period of limitation for any proceeding shall not take cognizance of their period in office; though, this does not change the fact that they are restricted from legal proceedings of any kind at this period.

This implies that persons covered by the immunity cannot be tried or compelled to attend court on any issue whatsoever, not only during their terms of office but after they finish serving their terms in respect of any issue that happened during their term of office. This is a particularly detrimental provision because it completely exonerates executive officials for any wrongdoing committed in office whether for public or private interest. No doubt, this emboldens politicians vying for the offices covered by immunity to dastardly plunder the Commonwealth of the people knowing that they will be exempted from application of the full weight of the law on them. Despite this provision, it is argued that persons to whom the section applies may be investigated in their dealings while in office, and if found liable for any criminal offences ultra vires their official functions, may be prosecuted after their terms of office. Again, the disadvantage of this argument is that time, money, and human resources spent investigating such officials may well be dissipated on an unfruitful venture because the length of 
time during which they may not be prosecuted may be used to compromise the investigation or conceal evidence of any wrongdoing. It is regressive to give a wrongdoer time and opportunity to do more evil in the pretext that if he is not immune, he will be distracted of his duties. We find the logic behind this principle lame, false and outdated; it is a principle that can never push a responsible democracy forward. Interestingly, subsection (2) of section 308 tends to limit the application of the immunity clause, however, tangential. It provides thus; "The provisions of subsection (1) of this section shall not apply to civil proceedings against a person to whom this section applies in his official capacity or to civil or criminal proceedings in which such a person is only a nominal party".

Here one may be provoked to pose the question, who is a nominal party? A nominal party is a party to a suit by virtue of his position as opposed to personal interest. Therefore, a nominal party by virtue of his position and office may have an interest in the subject matter of a suit, which warrants him to be joined as a party, but he will not be personally affected by any judgment given. This provision also shields office holders, in that they cannot appear in court for the wrongs of their appointed ministers or commissioners. It appears that the provision intends to systematically shield the office holder from all his failings as this negates modern democracy and forms a clog in the free flow of governance; it is against the rule of law and alien to the concept of good governance and justice. Section 308(3) (CFRN, 1999) captures the period in office of those shielded by this immunity clause which is usually a 4 -year term.

The section enumerates those covered by the clause and defines the period of office representing when a term of office still subsists. The present Constitution is not a 'peoples' constitution; it is a constitution borne out of military creed, ideology and mentality which leaves Nigeria with a permanent military identity until it is reversed. This is not the aspiration of many Nigerians but a few enriched by the charade of military regime. The positive law must at all times reflect the general will of the people; the government must be acceptable to the aspirations of the general will, to be obeyed (Ijalaye, 1993). Any government that considers its own interest above the general good is bereft of leadership and loses the right to be followed and obeyed. Thomas Aquinas ordered these in grades of inclination, so that those closely related to reason and sociality take priority over those concerned (for example) with procreation and self-preservation (Zalta n.d.). Like John Locke, who called for the preservation of all men, Hobbes on the other hand, called for self-preservation which Thomas Aquinas and Locke dissents. Selfpreservation is an apparatus or rationale for amassing wealth for personal aggrandisement as opposed to preservation for all.

\section{Immunity Clause in Other Jurisdictions}

This part we discuss selected jurisdictions and their respective practice of immunity. The bases for this is to compare the Nigerian perspective with these different jurisdictions to suggest better ways of incorporating executive immunity in the Nigerian Constitution in order to promote the rule of law, integrity and probity in governance. The considered jurisdictions do not practice absolute immunity (except Gambia); rather what they have is restrictive immunity as a way of accelerating governance, which Nigeria can emulate.

\subsection{Australia}

Australia is a federation; its Constitution can be considered as an amalgam of that of the United Kingdom and the United States (Australian Constitution [AC], Chap 1, Part 1). Immunity in Australia is not automatic and thus, it is largely implied or implicit. The Prime Minister is a member of the parliament and his immunity or privileges are as provided for other parliamentarians (AC, Section 49). It is a parliamentary system of Government with parliamentary immunity unlike Nigeria that operates executive immunity. More so, it deals with protecting parliamentarians from opinions made in the House of Parliament (Evans, 2016). In sum, the courts uphold parliamentary immunities, which protect parliamentarians and the citizens. They also uphold parliamentary powers, especially the power to punish contempt (Evans, 2016). In contrast, the Nigerian Constitution does not hold the executive President and his vice, the Governors and their deputies accountable for contempt for whatever reasons. Rather her style of immunity protects the executive heads by virtue of their office. No court in Nigeria can lawfully find these Nigerian leaders culpable or liable except when they serve out their term. While the Prime Minister of Australia enjoys few privileges by virtue of his office such as; accommodation, certain free travels or transport and salary, in Nigeria, immunity is centered not only on the enrichment of these leaders but is a tool to oppress the citizens. Similarly, while the crux for immunity of the Executive President and Vice President and all state governors including their deputies in Nigeria is to protect them from distractions from their official functions, the same reason is adduced by the Australian parliament for the punishment of contempt, yet the approach by both countries are at par.

The Crown's immunity is known as 'executive privilege' (Evans, 2016). This term refers to where executive Government is immune from presenting certain documents or information to the courts or to Parliament. (Evans, 
2016). Generally, there is no emphasis on the Australian Constitution that seeks to protect or shield individuals from crime in order not to distract them from their official duties as is espoused by section 308 of the Nigerian Constitution.

\subsection{Ireland}

The Irish Republic is a parliamentary democracy (Constitution of the Federal Republic of Ireland [CFRI], 1937; Panizza and Pavy, 2020). The Prime Minister like Australia does not have absolute immunity, he or she can be impeached for misbehaviour.(CFRI, Art 12). The Constitution does not define misbehavior but it captures the procedure for impeachment (CFRI Art 10). The President is subject to investigation. He can also be removed by a resolution of not less than two-third of the members of the House of the Oireachtason on the strength of such investigation where he is found guilty for misbehavior (CFRI Art. 10). The President has privilege from being arrested but treasonable offences are exempted from the privileges (CFRI Art. 10).

Conversely, the Nigerian Constitution affords her President and Vice President, governors of the states and their deputies absolute immunities from being arrested (1999 CFRN, section 308(1)(a)). In the history of Nigeria, none of these categories of leaders in their term of office has been tried or found culpable of treason. The Nigerian Constitution purports that they can do no wrong while in office and to bring charges or plaints against them will undermine or distract their daily functions in office.

\subsection{Italy}

The Constitution of the Republic of Italy (CRI) established a parliamentary system of Government (Panizza \& Pavy, 2020). The Parliament consists of the Chamber of Deputies and the Senate of the Republic. The President or the Prime Minister does not have absolute immunity. It is on record that Mr. Silvio Berlusconi is the first Prime Minister in Italian history to be convicted for embezzlement and corrupt enrichment. ${ }^{4}$ This is in contrast to the letters of the Nigerian Constitution. By virtue of the Nigerian immunity clause, a President or Vice president and their executive governors and deputies cannot be convicted for embezzlement or corrupt enrichment while serving their terms of office. They may be criticized or even investigated, but nothing empowers anybody to proffer a charge on the basis of such investigation until the expiration of their terms. The law in Italy provides that a member of the parliament cannot be questioned for the exercise of their function or deprived of their personal freedom (CRI Art 68). The law here is never at the detriment of citizens there seem to be a balance rights of parliamentarians and free speech by citizens unlike Nigeria.

The proviso in Article 68(2) of the Italian constitution suggests that for any member of the Parliament (Prime Minister inclusive) to be arrested, detained or subjected to search warrant, it must be authorized by members of the Parliament unless they are caught in an offence requiring an order of arrest mandatorily. The second limb of this proviso suggests that the Prime Minister as a member of the Parliament can be arrested without authorization; therefore, he or she does not have absolute immunity in the day-to-day running of the affairs of the Prime Minister's office. Similarly, Article 68(3) suggests that by authorization of the Parliament their private conversations and emails are subject to public scrutiny. In Nigeria on the other hand, the Executive President is not subject to public scrutiny; he is instead shielded in office for both criminal and civil matters until he fulfils his term of office. Whether he or she has a pending suit before being elected as President, Vice President, Governor or Deputy Governor, the moment they take the oath of office, they shall remain protected by section 308 of the Constitution (immunity clause) until they serve their terms in office.

While the Prime Minister can be tried for treason and can be impeached by majority of the Parliament in joint session (CRI), an incumbent president in Nigeria has never been tried nor is there a provision that subjects the President or state governors and their deputies to charges of treason or any public scrutiny. In the same vein as the Prime Minister, the President of the Italian Republic is accountable where he commits high treason or subverts the Constitution (CRI, Art 90). This is in contrast to Nigeria.

\subsection{Malaysia}

Malaysia is a federal constitutional monarchy that provides for a bicameral federal legislature (Federal Constitution of Malaysia [FCM], 1957). In Malaysia, it is possible to bring proceedings against the King or any ruler of a component state to the Special Court (FCM, Art 182). In the case of Sugumar Balakrishnan v Pengarah Imigresen Negeri Sabah the right to equality was affirmed by the court. While this is the case in Malaysia, in Nigeria by virtue of section 308, of Nigerian Constitution, the right of equality is impliedly impossible. The protection of a sitting executive leader from civil or criminal proceeding is a fundamental breach of the rights of Nigerian citizens and it creates substantial risk of oppression and repression of the rights of Nigerians. 


\subsection{Sweden}

Sweden is a constitutional monarchy. The Constitution is based on the principles of sovereignty, democracy, and parliamentarianism (Panizza and Pavy, 2020). The King does not enjoy absolute immunity. By using the word 'may' to qualify the immunity of the King or head of State, the Swedish Constitution makes executive immunity qualified rather than absolute (Swedish Instrument of Government [SIG] Art 7). On the other hand, there is parliamentary immunity by virtue of Chapter 4 of the Swedish Instrument of Government. The Prime Minister is vested with executive authority. However, the Constitution does not intend for an absolute immunity for the Prime Minister who is saddled with the highest executive power because he is not lord over himself but accountable to the people and for his actions while acting as the Prime Minister. In comparison with Nigeria, there is wide difference in the practice of immunity between these two countries. In Nigeria, the practice of immunity clause avails protection to executive offices and puts Nigerian citizens at the whims of their leaders.

\subsection{Gambia}

Under the Constitution that was ratified in 1996 and went into effect in 1997, the Gambian President is the head of State and head of Government (Constitution of Gambia [CG], 1977). By virtue of section 69 of the Constitution, Gambia is a country with restrictive immunity. However, on matters pertaining to the enforcement of the Constitution the President has absolute immunity. Thus the Constitution makes the President immune from civil and criminal matters albeit with a proviso (CG Sec 69 (2)).

The combined effect of these provisions is such that the Gambian Constitution gives the President absolute immunity but a matter, which contravenes the Constitution, can be enforced in a court of competent jurisdiction as far as it contravenes the provision of the Constitution. The danger in this provision is that it is authoritarian like the Nigerian Constitution; it pays heavy reliance on the immunity of the president from criminal and civil proceedings. The constitution also shields past military leaders by virtue of sections 11, 13 and 14 of the Second Schedule of the Constitution. Similarly, it envisages protection for leaders like the President while putting the citizens at risk of being oppressed like the case of Nigeria.

\subsection{United States}

Executive immunity in the United States of America is not absolute in criminal matters. In Nixon v. Fitzgerald, it was decided that the president has absolute immunity and therefore free from legal liability in civil matters. But he does not have absolute immunity for criminal charges. He can be charged for criminal offences during his term of office whether the act committed is official or non-official. In Jones v. Clinton (1997), it was restated that the President enjoys absolute immunity on civil matters alone. The immunity does not include wrongs committed before assuming office as President. Thus, the president is liable in civil proceedings for wrongs committed before assuming office even while already in office. This is almost complementary to the Nigerian immunity for civil proceedings. However, the moment those entitled to executive immunity under the Nigerian constitution assume office, no civil proceedings can arise for wrongs committed before assuming office. It is proposed that the practice of absolute executive immunity (in criminal and civil proceedings) is obsolete for any progressive democratic government and therefore, the immunity clause as enshrined in the Constitution of Nigeria should be reviewed to curtail the excesses of these categories of leaders.

In the case of Illinois Governor of the United States, Rod Blagojevich, who had a conversation with one of the candidate's advisors on who may replace Obama in the Senate and where he commented that the senate seat "is a valuable thing that you don't just give it out for nothing", he was arrested, charged and convicted for wanting to sell the vacant seat in the Senate (Schor, 2008).

Considering the different jurisdictions above where the power of executive immunity has been whittled down, it is trite to state that this is not a matter of sampling other jurisdictions, but a call to consider the peculiar exigencies in Nigeria and to quash the provision (Falana, n.d.). It has rather become evil in Nigeria because it negates the will of the people. The volume of public funds looted in Nigeria by public officials, especially officials covered by the immunity clause is staggering, rising to over $\$ 100$ billion (Enweremadu, 2013). Most of these monies cannot be recovered from the different jurisdictions where they were laundered, and the culprits have also absconded as fugitives to other countries (Enweremadu, 2013). The former Economic and Financial Crimes Commission boss Mr. Nuhu Ribadu pointed out corruption as one of the greatest challenges to successive Nigerian governments. He noted that between 1960 and 1999, government officials have stolen more than $\$ 440$ billion (Ribadu, 2007). It is logical to say that since power belongs to the people, elected officials must be made accountable to the same people who voted them to office. 


\section{Conclusion}

This paper is a critique of the constitutional provision of executive immunity under the 1999 Constitution of the Federal Republic of Nigeria. We explained the origin and meaning of this clause in Nigeria and other jurisdictions. We are inclined to believe that there is a need for reform of the provision, and we have substantiated this fact jurisprudentially extrapolating from the experiences in other jurisdictions where we showed that political representatives holding the exalted offices of president, head of state or prime minister do not enjoy absolute immunity for all wrongs committed before or during their terms of office.

Consequently, it is our view that the immunity clause contained in section 308 of the Nigerian constitution be restricted to only civil matters, such as breach of contract, land matters or torts. Criminal matters pertaining to forgery, impersonation, fraud, murder, terrorism, kidnapping, cybercrime, rape and money laundering must be investigated and pursued against those holding executive power, whether committed before or during the pendency of their term of office. Governance should rest on the ideals of equality, fairness and justice. Nigeria, like Australia, Ireland, Italy, Malaysia, Sweden, Gambia and the United States must hold her leaders answerable for crimes and wrongs committed as executive heads of government.

On their part, the judiciary must remain independent, create a balance between good governance and protection of citizen rights, and hold perpetrators of embezzled public funds to justice and accountable to the people.

\section{Acknowledgement}

The authors would like to thank Dr. Hemen Philip Faga of the Faculty of Law, Ebonyi State University Abakaliki, Nigeria, for his support in this work.

\section{References}

Aguda, O. (2000). Understanding the Nigerian Constitution of 1999. Lagos: M.I.J. publishers.

Akinpelu, Y. (2020). Orji Kalu Resumes at Senate after Release from Prison. Premium Times (June 09, 2020) Retrieved October 5, 2020, from https://www.premiumtimesng.com/news/topnews/396826-orji-kaluresumes-at-senate-after-release-from-prison-.html

Ameachi, U. (2004). The Jurisprudence of the Nigerian Legal Order: Positivism and the State. Ecowatch publication Nig. limited, Lagos.

Appadorai, A. (2004). The Substance of Politics. Oxford University Press, India.

Austin, J. (1995). Austin: The Province of Jurisprudence Determined. In W. Rumble (Ed.), Cambridge Texts in the History of Political Thought. Cambridge: Cambridge University Press. https://doi.org/10.1017/CBO9780511521546

BBC News. (2014). The many Trials of Silvio Berlusconi Explained. B.B.C. News. London. Retrieved October 3 , 2020, from https://www.bbc.com/news/world-europe-12403119

Chuks, A. J. (2020). Nigeria: Immunity Clause Hindering Corruption War - Lawyers. Daily Trust Newspaper February 18, 2020. Retrieved September 22, 2020, from https://allafrica.com/stories/202002180078.html

Daudu, K. A. (2010). To Retain or Remove? The Jurisprudence of the Immunity Clause in the 1999 Constitution of the Federal Republic of Nigeria. Ebonyi State University Journal of International Law and Juridical Review, 1.

Eghosa, E. O. (1998). Nigeria since Independence: Crippled Giant.

Encyclopædia Britannica. (2010). Encyclopaedia Britannica Student and Home Edition. Chicago: Encyclopædia Britannica.

Encyclopædia Britannica. (2020). Sani Abacha. Retrieved December 5, 2020, from https://www.britannica.com/biography/Sani-Abacha

Eniola, A., \& Tobi, A. (2019). In Case You Missed It: Nine Ex-Govs Whose corruption Cases are forgotten. The Punch Newspapers, December 9, 2019. Retrieved September 25, 2020, from https://punch.com/nine-ex-govswhose-corruption-cases-are-forgotten/?amp=1

Enweremadu, D. (2013). Nigeria's Quest to Recover Looted Assets: The Abacha Affair. Africa Spectrum, 48(2). https://doi.org/10.1177/000203971304800203

Evans, H. (Ed.). (2016). Odgers' Australian Senate Practice (14th ed., Chapter 2). Department of the Senate, $\begin{array}{lllll}\text { Canberra. } & \text { Retrieved } & \text { September } & 30, & \text { 2020, }\end{array}$ 
https://www.aph.gov.au/about_parliament/work_of_the_parliament/parliament_at_work/parliamentary_priv ilege

Falana, F. (2010). What has happened to Nigeria's \$12bn Oil Windfall of 1991. Retrieved July 13, 2020, from www.gasandoil.com/gol/news/nta63739.htm

Fombad, C. M., \& Inegbedion, N. (2010). Presidential Term Limits and their Impact on Constitutionalism in Africa. In C. Murray, \& C. M. Fombad (Eds.), Fostering Constitutionalism in Africa. Pretoria University Law Press.

Fombad, C. M., \& Nwauche, E. (2012). Africa's Imperial Presidents: Immunity, Impunity and Accountability. African Journal of Legal Studies, 5(2). https://doi.org/10.1163/17087384-12342001

Garner, B. A. (2004). Black's Law Dictionary (8th ed.). Thomas West U.S.A.

Gberie, L. (2016). Crime, Violence, and Politics: Drug Trafficking and Counternarcotics Policies in Mali and Guinea. Retrieved September 28, 2020, from http://globalinitiative.net/wpcontent/uploads/2018/01/Brookings-Crime-Violence-and-Politics-Drugs-Trafficking-and-CounternarcoticsPolicies-in-Mali-and-Guinea.pdf

Gross, L. (1948). The Peace of Westphalia, 1648-1948. The American Journal of International Law, 42(1). https://doi.org/10.2307/2193560

Hornby, A. S. (2001). Oxford Advanced Learners Dictionary of Current English. New York: Oxford.

Human Rights Watch. (2011). Corruption on Trial? 'The Record of Nigeria's Economic and Financial Crimes Commission': Human Right Watch. New York. Retrieved October 5, 2020, from https://www.hrw.org/report/2011/08/25/corruption-trial/record-nigerias-economic-and-financial-crimescommission

Ijalaye, D. A. (1993). Natural Law and Nigerian Experience. Lagos, M.I.J. Publishers.

Mcnair, A. (Ed.). (1928). Lassa Oppenheim. International Law: A Treatise. Lond. $4^{\text {th }}$ ed.

Murphy, M. (2019). The Natural Law Tradition in Ethics. The Stanford Encyclopaedia of Philosophy.

Ogugua, V. C. I. (2013). The Imperative of Removing Immunity Clause in the Constitution of the Federal Republic of Nigeria 1999. Nnamdi Azikiwe University Journal of International Law and Jurisprudence, 4.

Okeke, M. I., Ojukwu, U. G., \& Nnamani, D. O. (2019). The Implication of Immunity Clause and the Pollution of Excellency for Democratic Consolidation in Nigeria. International Journal of Academic Management Science Research, 3(11).

Olanipekun, W. (2005). D.S.P. Alamieyeseigha's Trial Against International Law. The Guardian Newspaper, Tuesday, October 18, 2005.

Oliver, H. (2020). (The Guardian-Jerusalem Sunday, May 24, 2020:01:13 EDT) "Netanyahu in the Dock: Image of Israeli PM on trial may haunt him forever". Retrieved July 10, 2020, from https:/www.theguardian.com/world/2020/may/24/netanyahu-in-the-dock-image-of-israeli-pm-on-trialmayhaunt-him-for-ever

Olugbenga, E. O. (2012). 'The Significance of the Immunity Clause for Democratic Consolidation in Nigeria. African Journal of Criminology, 6.

Olukomaiya, F. (2019). Meet 6 Nigerian Ex-governors who have been to Prison. PM News Nigeria December 11, 2019. Retrieved October 5, 2020, from https://www.pmnewsnigeria.com/2019/12/11/meet-6-nigerian-exgovernors-who-have-been-to-prison

Organisation for Security and Co-operation in Europe. (2005). Toolkit to Combat Trafficking in Persons. Tool 9.2, Addressing the Root Causes of Trafficking. Retrieved September 28, 2020, from www.osce.org/document/pc/2005/07/15594_en.pdf

Oyewole, A. (1987). Historical Dictionary of Nigeria. Scarecrow Press N.J. \& London.

Panizza, R., \& Pavy, E. (2020). European Parliament: Handbook on the Incompatibilities and Immunity of Members of the European Parliament. Directorate - General for Internal Policies PE 621.936.

Ribadu, N. (2007). Corruption Fight Back. Zero Tolerance, 3(1).

Schor, E. (2008). Illinois Governor Charged with taking Bribes for Obama's Senate Seat. The Guardian Washington, December 09, 2008. Retrieved October 5, 2020, from http://www.theguardian.com/world/2008/dec/09/illinoise-obama-senate-rod-blegojevich 
Tajudeen, I. O. (2013). Executive Immunity in Nigeria: Putting Off Old Garments. Journal of Politics and Law, 6(3). https://doi.org/10.5539/jpl.v6n3p189

U.S. Write House. (2014). Immunity or Impunity. Retrieved September 22, 2020, from http://writehouse.org/immunity-or-impunity

Udeh, P. (2009). Immunity of Sovereign States - Historical and Contemporary Perspectives. Nigerian Journal of Public Law, 2(1).

Ukoh, F. N. (2018). State Sovereign Powers: The Challenges of Terrorism. Human Rights and Jurisprudence Journal, 4.

Umoru, H. (2020). Call for Memoranda by the Senate Ad-Hoc Committee on the Review of the 1999 Constitution "Constitution Review: Senate commences process, calls for memoranda". Vanguard Newspaper On August 25, 2020. Retrieved September 22, 2020, from https://www.vanguardngr.com/2020/08/constitution-reviewsenate-commences-process-calls-for-memoranda/

Zalta, E. N. (n.d.). The Natural Law Tradition in Ethics. Stanford Encyclopedia. Stanford, September 28, 2020. Retrieved September 28, 2020, from https://plato.stanford.edu/index.html

\section{Notes}

Note 1. The former state governors currently facing trial for corruption in Nigeria are: (1) Timipre Sylva - former governor of Bayelsa State from 2008 to 2012 (currently facing trial for laundering the sum of N19.2bn). He has been appointed minister of state for petroleum since 2019 by the Buhari administration. (2) Danjuma Goje - former governor of Gombe State arraigned in court for diverting N5billion under the guise of supply of dictionaries and food. He is currently a serving senator of the federal republic. (3) Godswill Apkabio, former governor of Akwa Ibom state, accused of mismanaging N108bn belonging to the State. He was appointed in 2019 as minister of Niger Delta Affairs by the Buhari Government. (4) Aliyu Wamako, he was governor of Sokoto State from 2007 to 2015. Since 2015 has been under probe by the EFCC for alleged N15bn fraud and has not been charged to court to date. (5) Peter Odili was governor of Rivers State from 1999 to 2007. Interim Report by EFCC stated that over N100bn was diverted by the Governor, allegations of fraud, conversion of public funds and Money Laundering etc. (6) Sulivan Chime was governor of Enugu State from 2007 to 2015. He is accused of mismanaging the resources of the State and receiving part of the N23bn alleged shared by Diezani Allison-Madueke, a former Minister of Petroleum Resources. (7) Ali Modu Sheriff was the governor of Borno State. His Government was accused of having received and mismanaged over N300bn from the Federation account. (8) Rabiu Kwakwanso is the former Governor of Kano State. The EFCC allege that he illegally used Local Government funds allocation in his state to fund his presidential campaign.

Note 2. For instance Israel recently docked its Prime Minister Benjamin Netanyahu on allegation of corruption. Article II(4) of the United States Constitution provides for impeachment for President, Vice President and all Civil Officers of the State if convicted for treason, bribery and other high crimes as misdemeanors. E.g., President Andrew Johnson was impeached in 1868 for abuse of power; President Richard Nixon was investigated for abuse of authority and obstruction of justice in the Watergate scandal, and he resigned in 1972 before he was to be impeached.

Note 3. For instance, it was discovered that the late General Sani Abacha and his family looted well over $\$ 3$ billion, most of it held in European banks. In 2002, the government of Chief Olusegun Obasanjo reached a settlement with the family to return some of the money in exchange for dropping criminal prosecution.

Note 4. He was convicted in 2013 for abuse of power and sentenced to 7 years in jail and never to hold public office again for paying for sex with an underage prostitute. He was also found to have abused the powers of his office.

\section{Copyrights}

Copyright for this article is retained by the author(s), with first publication rights granted to the journal.

This is an open-access article distributed under the terms and conditions of the Creative Commons Attribution license (http://creativecommons.org/licenses/by/4.0/). 